\title{
Challenges of Student Mobility in a Cosmopolitan Europe
}

\author{
Janine Wulz and Florian Rainer
}

\section{Introduction}

The CoSMiCE project focuses on student degree mobility in Europe from a student perspective. Students' unions all over Europe, representing 11 million students, discussed the benefits and challenges of student mobility and defined the key impact factors of a country's approach towards student mobility. This chapter puts spot on these factors and discusses their impact on European student mobility.

\subsection{The CoSMiCE Project}

CoSMiCE, an acronym for Challenges of Student Mobility in a Cosmopolitan Europe, is a project organized by the Austrian Students' Union (ÖH) and the Slovakian Students' Union (SRVS). This student project tries to link up with challenges and barriers of degree mobility perceived by students, and seeks to raise awareness in this dynamic process. Our focus on degree mobility is targeting students studying abroad which are following a full study programme. In order to sensitize the participants for the overarching theme of degree mobility, ÖH and SRVS organized a European wide seminar in Bratislava from 29.04. to 01.05.2014.

J. Wulz $(\square)$

University of Applied Science FH Campus Wien, Vienna, Austria

e-mail: janine.wulz@oeh.ac.at

F. Rainer

Austrian Student's Union, Office for International Affairs, Vienna, Austria

e-mail: florian.rainer@oeh.ac.at

(C) The Author(s) 2015

A. Curaj et al. (eds.), The European Higher Education Area,

DOI 10.1007/978-3-319-20877-0_4 
Representing a European-wide study, the CoSMICE project polling 47 students' organizations and 10 in-depth country studies in Armenia (ANSA ${ }^{1}$ ), Austria (ÖH), Belgium $\left(\mathrm{VVS}^{2}\right.$ ), Denmark (DSF), Estonia (EÜL), Finland (SYL/SAMOK), Germany (fzs), Latvia (LSA), the Netherlands (LSVB) and Poland (PSRP), provides a qualitative insight in European students' degree mobility from the perspectives and experiences of students' unions. The questionnaire was distributed to all 47 National Unions of Students (NUS) from 39 countries that are members of the European Students' Union (ESU). This survey, which had over 20 open questions $^{3}$ relating to degree mobility, has been approved by representatives of several unions (VSS-UNES-USU, FZS, SRVS, ÖH and ESU). As countries within the EHEA differ strongly in their shares of incoming and outgoing students, the sample of states chosen for CoSMICE cover a wide range in this spectrum.

Austria and Germany have high shares of incoming mobile students and outgoing mobile students studying abroad, though Austria has $5.4^{4}$ more incoming mobile students than outgoings, Germany has a ratio of 1.8. Denmark shows a low number of outgoing students, the incoming mobile students are more than threefold. Belgium, Finland and the Netherlands have average mobility flows in relation to other EHEA countries. Estonia and Latvia are representing countries with a high outbound ratio. Armenia, a Non-EU country, and Poland are having both low shares of incoming mobile students and low shares of outgoing mobile students ${ }^{5}$ (cf. UNESCO 2010).

The method of content analysis (Bohnsack 1997) was used to analyse the answer patterns provided by the respondents. Six main factors that have an impact on student mobility itself and the perception of student mobility in the national context have been isolated. Those impact factors-Recognition, Tuition Fees and Restrictions, Financial Support, Social Support, Public and Media Perception, Brain Gain and Brain Drain - explain the diverse perceptions of European countries regarding student mobility, as well as the diversity of concepts dealing with incoming students. According to the authors, the clusters are reflecting the perceptions of students' unions to present a picture of the challenges and national variations across the European Higher Education Area. Moreover, the student project will be summarized by a publication with several contextualizing articles and interviews, which has been released in February 2015.

\footnotetext{
${ }^{1}$ Please find the full name of the unions' abbreviations as annex.

${ }^{2}$ Represents only the students in the Flemish community of Belgium.

${ }^{3}$ E.g. Are there problems with recognition/nostrification perceived by your union?

${ }^{4}$ Import-export ratio divides the net incoming mobile students by outgoing mobile students.

${ }^{5}$ For detailed information please have a look to the study of IHS Austria (Grabher et al. 2014) regarding calculations on degree mobility flows in the EHEA.
} 


\section{Student Mobility in Europe}

Internationalisation of higher education is gaining momentum among policy makers, as well as practitioners at European, national and institutional levels. Internationalisation includes degree mobility and credit mobility. While degree mobility is conducted with the purpose of completing a whole cycle, to acquire a degree of Bachelor, Master or PhD., hence it is different from credit mobility, where students remain enrolled in their home institution and leave it to gain single credit points (ECTS). Other forms of internationalisation are cross-border delivery of education, as well as formats of 'internationalisation at home', like internationalisation of the curriculum, internationalisation of teaching and learning, and internationalisation of learning outcomes.

In the 1970s, the European Union started to cooperate on education and started first actions to enable mobility in higher education. Since the 1990s, international dimensions in higher education have become more reflected in policies, finances, strategies and research (Kehm 2011). The ERASMUS program already started in 1987. In 1999, by adopting the Lisbon strategy and starting the Bologna Process, the European Higher Education Area was established. In 2012, the Mobility 2020 strategy was adopted, promoting "high quality mobility of students, early stage researchers, teachers and other staff", including a mobility target by 2020 "at least $20 \%$ of those graduating in the EHEA should have had a study or training period abroad". The Communiqué by the European Commission "European higher education in the world" (European Comission 2013) launched in 2011, outlines in its strategy the promotion of international mobility of students and staff, for example through enhanced services for mobility, tools for recognition of studies, better visa procedures for foreign students and emphasis on two way mobility-into and out of Europe. Moreover, "internationalisation at home" and cooperation, for example in the field of joint degrees, are promoted.

Beside other factors, as learning foreign languages, internationalisation of curricula or knowledge transfer, physical mobility is the most visible part of internationalisation. Student mobility is enabled by the key factor of recognition of degrees and academic achievements (Teichler 2009). To grant the recognition for ERASMUS-supported and other mobile students, the European Credit Transfer System is being established since 1989.

The increasing number of mobile students indicates that the concept of internationalisation in European higher education has been subject to further development over the last twenty years "from the fringe of institutional interest to the very core" (De Wit 2011, p. 7).

International student mobility is figurated by an "outcome of a complex interplay of external and internal push and pull variables" (Rahul and De Wit 2014, p. 7).

A recent study (Niederl and Bader 2014) in Austria defined numerous factors for international student mobility: Push factors can be personal, such as the socio-economic situation, the individual academic abilities, social relationships, former international experiences. Other factors might be related to the situation in 
the home country, such as the opportunities at home universities, quality of national offers or a high relevance of international degrees at the home-countries labour market. Moreover, financial opportunities (scholarships, loans), demographic, economic and political framework, living standard and living costs are relevant. Pull factors could be related to the field of study, the quality and reputation of higher education institutions, scientific freedom or a multilingual study offer. Other factors are related to service, as information on the host country, administrative support, recognition of degrees and qualifications, cooperation with international institutions and networks. A third group of pull factors are related to the place of study: study and living costs, security, openness, international communities living there, living and working standards and career perspectives, as well as cultural, economic, educational, language, political and religious reasons. Other factors are cultural offer, public services, public transport system or the climate (Niederl and Bader 2014). Mobility, as an important factor of internationalisation, is driven by various interests, aiming for international cooperation, but also facing competition and economic factors (Knight 2010). On the one hand, student mobility supports knowledge transfer, mutual understanding and peace, and provides opportunities for personal development as global citizens, and engagement in global networks (Hénard et al. 2012; Teichler 2009). On the other hand, student mobility is more and more influenced by market processes, such as orientation on global rankings, or the fact that international students are increasingly seen as a source of additional revenues from exports of higher education services (OECD 2013a).

Commercial interests are not the only challenge internationalisation and mobility have to face. Another challenge is imbalanced mobility flows that can lead to conflicts concerning funding and admission policies (Pechar 2009). The loss of intellectual capital, the so called 'brain drain', is a main source of concern in developing and emerging countries (EAHEP 2010), and individual challenges can mean additional burdens, such as costs and high risks for individuals as far as success is concerned (Teichler 2009).

Following from that, it can be said that internationalization of higher education might be led by different factors, such as political strategies for economic and or diplomatic reasons, the improvement of a country's home education system or the promotion of country and culture, though two central characteristics can be prescinded (Hawawini 2011). In consequence, we can assume that cooperation and competition move from margin to centre.

In the following, we will focus on student mobility as an important aspect of internationalisation. In 2013, more than 4.3 million students were mobile worldwide (OECD 2013a, b). In a real European Higher Education Area, according to the Communiques of the Commission, students are able to move freely across Europe and are no more bound to national borders when choosing their preferred university for their studies. Apparently, this goal is yet to be achieved. With the implementation of the Bologna Process, the EHEA has taken significant steps to its full realization; however, numerous challenges are still to be overcome. Moreover, several aspects should be re-problematized. In this chapter we discuss the diverse realizations and enablings of student degree mobility in a Cosmopolitan Europe. 


\section{Impact Factors on European Student Mobility}

\subsection{Recognition}

Recognition is an essential prerequisite to ensure mobility, as signed in the Lisbon Recognition Convention (2007). All countries participating in the survey offer access to professional recognition and information centres for proving the students' qualifications; professional recognition and information centres for proving; in addition they are part of the ENIC/NARIC network to ensure transparent and reliable procedures. Still, students' unions of the reporting countries describe that the procedures of recognition are accompanied by diverse challenges and obstacles. Furthermore, there is no exact data available on the work of the national education bodies, apart from Belgium and Germany, which reported that 25-30 \% (SVR für Migration 2012) of the enquiries were rejected. In most countries (AT, DE, DK, ES, NL, PL), the recognition depends on the Council appointed at the faculty level of the particular institution whether a diploma is approved or not. "Therefore it is a subject of discussion", LSVb (NL) states. PSRP (Poland) opines that "there is no clear process of appeal if a diploma is rejected, which causes doubts". If your application doesn't meet all the requested entry requirements, higher education institutions oblige you to do supplementary examinations. It is a common way to full recognition to complete supplementary courses before or shortly after starting the programme, ÖH (AT), DSF (DK) and PSRP (PL) report. Exceptions to the conventional recognition process are bi- or multilateral agreements concluded by governments, which allow a simplified procedure for certain degrees and certificates to enter the higher education sector.

Moreover, there are financial obstacles that students must take. Students holding foreign qualifications are subject to admission expenses and, at the same time, expenses to prove the equivalence of their certificates. The Austrian Students' Union denotes that the procedure of recognition can take up to 3 months with costs of $€ 150$ plus extra administration charges. In Germany there are costs of $€ 43$ for EU students and $€ 68$ for Non-EU students for getting the diploma recognized at a particular higher education institution. "Indirect fees for non EU citizens are raised via those application expenses", fzs (DE) observes. Non-EU country students are facing problems to a greater extent with recognition processes, due to political regulations and different structures in their higher educational institutions' curricula.

\subsection{Restrictions and Fees}

In all participating countries the legal body entrusted with admission to higher education programmes is the very HEI itself. Nevertheless, in all countries there are also general policies that relate to admission. This creates different forms of entrance qualifications, as well as a lack of transparency in handling the access to higher education. 
In most countries (AM, BE, LV, NL, PL) higher education institutions are charging incoming students with tuition fees, as well as their own citizens, though there is the tendency to charge incoming students generally higher. Significant distinctions of charges can be seen between EU, EHEA but Non-EU and NonEHEA countries. Furthermore, the amount of fees depends on the language in which the programme is held; programmes in English are calculated with additional fees, as reported from EÜL (ES), LSA (LV) and PSRP (PL). Students in Austria and Germany do not have to pay tuition fees while studying within the minimum of duration of their particular programme, plus two and four semesters respectively of tolerance. Consequently, different patterns to the levying of fees can be deduced:

- Fees for international students are higher than for domestic students (LV)

- Fees for Non-EU students are higher than for domestic students (AT, BE, NL)

- Fees for Non-EHEA students are higher than for EHEA students (DK, ES)

- Countries make no distinction between international and domestic student fees (AM)

- Countries are not charging tuition fees from foreign students (FI)

- Fees are contingent upon the language in which the programme is held (ES, LV, PL)

- Fees are contingent upon the duration plus semesters of tolerance (AT, DE)

- Students from developing countries - as defined by the respective governmentdon't have to pay fees or get just a minimum charge (AT, BE)

The level of tuition fees varies enormously; moreover, it is tied to various conditions, such as the country of origin of the student, the programme the student is enrolled in and the language of instruction. Estonia, for example, doesn't charge students from the EHEA if they study in Estonian language, though they charge students for programmes taught in English and students outside of the EHEA. Austria levies $€ 363$ from EU students and a twofold amount from Non-EU students. In Latvia, in the Netherlands or in Denmark the fees for certain programmes can cost up to $€ 20.000$ per academic year.

Further access arrangements can be quotas for particular study programs or restricted access in the so called mass disciplines by acceptance tests or by numerus clausus. Restrictions in the fields of study related to health science have been reported in Austria, Latvia and the Netherlands. The acceptance of only a significant number of applicants in medical subjects due to limited resources got Austria and the EU to agree on a special authorization, until 2016 up to every fourth university place is awarded to Non-Austrian students, thereof $20 \%$ EU citizens and $5 \%$ Non-EU students. Limited places and restrictions based on high school grade average, the so called numerus clausus, is a common practice in Germany and the Netherlands. Above all, an essential requirement is the ability to communicate in the given language, which has to be proven by certificates of a language proficiency test. 


\subsection{Financial Support}

Within the European Union, diverse financial support mechanisms for student mobility exist, consisting of grants, loans, exemptions from fees or scholarships. There are different restrictions and various ways to access the subsidies of each country. Moreover, in every country, specific bilateral agreements allow particular incoming students getting portable grants and scholarships for certain degrees. Armenia, for example, offers financially supported study places in intergovernmental or international projects. In Denmark, the availability of scholarships is supported by all higher education institutions and the government. Likewise for EU, EEA and Swiss students can receive the same grants (about €780) as Danish students but linked to several requirements. Students can receive these scholarships in other countries (DK, FI, NL) as well, mostly under the terms of visa, residence permits, work permits or a work permit of their parents in the hosting country. Consequently, different patterns of financial support can be deduced:

- Grants and loans are available

- The host country offers only individual based scholarships

- Grants are only accessible by certain requirements

- Requirements: Country of origin, visa, residence and work permits, particular subject, parental income

Additionally, it can be perceived that governments pay subsidies in different rates according to the subjects (DK, ES). Estonia offers only scholarships for special subjects, like IT or engineering, further, they are only accessible if the course of studies is in Estonian language. Foreign students are not entitled to apply for student loans, but they have the right to receive educational grants similar to Estonian students. Germany offers individual based scholarships. To be eligible as a mobile student for a grant of $€ 500$ in Latvia on academic year has to be completed, yet loans in Latvia have the same conditions for every student, regardless of the country of origin.

When it comes to financial support for outgoing mobile students, the situation is diverse as well. Every participating country in this study has its very own financial mechanisms to support outgoing students, except Denmark and Finland which have concluded together with Iceland, Norway and Sweden the Nordic Agreement in 1996 (Nordic Council of Ministers for Education and Research 2012). The agreement has been set up to finance the imbalanced mobility and to increase the opportunities for students. "This means that students from the Nordic countries, who apply for public courses and programmes in other Nordic countries, are automatically granted admission if they hold the right qualifications for the programme. Also, the agreement establishes reciprocal recognition of all forms of examinations and descriptions or statements of educational attainment”, DSF (DK) reports. The annual reimbursement in 2014 is approximately $€ 4025$ per student.

Austria established mobility scholarships based on the income of the students' parents, while Denmark pays subsidies to the tuition fees in the respective country. 
LSVb (NL) reports that they have a portable grant system as well. Finland offers mobile grants and loans; this financial support consists of a grant (€298), housing supplements (max. $€ 210$, depending on the country) and an optional loan guarantee (up to $€ 600$ ). PSRP (PL) states that they have "private scholarships for incomings, but outgoing students are not allowed to apply for loans and need or merit based scholarships in Poland when they study abroad (even within EHEA)." Germany makes their national student support system (BAföG) also available for outgoing students with the same terms and requirements, though not every student is eligible for this support scheme. "The applicability depends mainly on the parents' income, the age and the study progress. For studying in other EU countries or in Switzerland the whole programme time is supported. For studies beyond the EU, in most cases just one year is supported by BAföG. BAföG is half a loan and half a grant", fzs (DE) explains.

\subsection{Social Support}

The social support of students is organized differently but almost all participating countries provide information about their particular higher education location via several media. Beyond that, countries or the individual institution offer guidance and consultation services, as well as social activities alongside academic duties. Armenia is currently creating a supporting network for students and the other reporting countries already established a network of social support. Austria has a widely elaborated informational and social supporting network offered by universities and the Austrian Students' Union. A lot of higher education institutions have an Office for International Affairs, as well as buddy networks (AT, BE, DK, ES, FI, DE, LV, NL, PL), which promote social contacts among foreign and local students. Furthermore informational campaigns and webpages are common to assist students at their new location, by providing information on deadlines, orientation or special dispositions. Orientation weeks are organized for example in the Netherlands, which are linked to a program called 'Make it in the Netherlands' that "aim is to make international students feel more at home", LSVb (NL) states. Estonia provides as well a tutor system, which assists foreign students with their daily issues. Germany moreover offers welcome packages, regularly scheduled events and cultural activities. PSRP reports that Poland is above all preparing their students for going abroad.

Yet, another factor of social support is the inclusion of students by language, therefore Austria, Belgium and Poland report that they offer courses with special allowances. Latvia organizes several university students' councils in English language, so foreign students can get involved more easily. "Latvian language courses are even required in Latvia if you stay longer than half a year", LSA states.

The housing situation is reported as being challenging for foreign students because of hindered access to information and rental requirements, like a work permit or a particular amount of income. In Belgium and Germany some student 
accommodation places are reserved for incoming students. In Finland the student housing is ruled by Non Profit Organizations and "the queues are quite long", SYL and SAMOK explain the obstacles they are facing.

\subsection{Media Perception}

The public and media perception of international students can be regarded as merely positive, though there are aspects of scepticism and criticism, mainly related to the funding of higher education, financial benefits and employment issues. Among European countries, the degree and profile of student mobility flows diverge. On the one hand, there are countries that accept more students than they send out, and on the other hand there are countries which send out more students than they accept. Therefore student degree mobility is perceived in different manners around the EHEA.

ANSA (AM), VVS (BE) and EÜL (ES) have no information on their media perception since this matter isn't an object of public discussions. SYL and SAMOK (FI) report that there is not much debate on this topic in Finland, though "they very welcome foreign students within the academic community". In Denmark, for example, eastern European students - after the EU verdict-are seen as "welfare tourists" (DSF) who have now access to university and grants, while employers in Denmark point out that they wish to have more international talents to choose from. Others see the international students as a valuable contribution to society and its educational system, as they contribute with new perspectives. It often can be observed that countries with a high share of incoming mobile students, such as Denmark or Austria, portray the incoming students as people who take away university places when studying for free. Though the discussion in Austria isn't completely internationally focused, Austrian media reports are merely concentrated on German students who are stylized and typified as evaders of their Numerus Clausus system. In return, Germany is a favoured destination in Europe; "nonetheless Germany is a net exporter and the media reports mainly on incoming students. Newspapers narrate that only one out of two international students are actually graduating", fzs (DE) denotes.

The DAAD study (2014), which demonstrated the positive effect in several respects - academic and economic - of international students, however, was important for the positive public perception in a lot of countries, Students' Unions of Austria, Germany, the Netherlands and Poland report. LSA (LV) shares a similar appraisement; it considers incoming students as a "treat to the states' economic development in long terms", as well as the Netherlands, who try to stimulate the mobility flows. Therefore, all political parties are gathering and working out strategies for the realization of a balanced internationalization strategy. In 2013, they already launched a plan to make the Netherlands a more attractive country for international students. "International students are mainly seen as value, also in economic matters", LSVb (NL) reports. 
Poland perceives international students as a valuable part of the internationalization of higher education. Consequently, they try to make studying in Poland more attractive, since they are regarded as beneficial for the development of their country. "They are seen as a motivator to improve public administration. Creating comfortable conditions for foreigners is one of our priorities, both in academic and general contexts", PSRP (PL) describes the public perception.

\subsection{Brain Drain and Brain Gain}

Accompanied by the international student mobility flows, emigration and immigration depend on structural conditions and prerequisites of the higher education sector and labour market issues. Therefore, there is a public debate and, in a sense, a competition for top students. It is discussed as a significant advantage and considerable benefit to get and keep these students, and as a disadvantage for countries that do not have the means to keep their students.

Armenia and Belgium have no information on Brain Drain, (n?) or on Brain Gain. LSA (LV) reports "brain drain affection due to a high unemployment rate, it is seen that a lot of incoming students leave the country after finishing their degree." PSRP (PL) perceives similar consequences? Effects, trends?, "it is said that insignificant percentage of incoming students stay in Poland after finishing". Even for Austria it is hard to make the foreign students stay, due to the insufficient resources and available prospects in work. Therefore, Austria established the RedWhiteRed-Card, a special working permit for qualified employees from Non-EU countries (Federal Ministry of the Interior 2014), though only 213 out of 1700 student applicants from Non-EU countries got it in the year 2013 (Der Standard 2014). Staying in a country is primarily linked to working conditions; however language requisitions are described by ÖH (AT) and LSA (LV) as the main barrier. Following from that, these countries perceive effects and are aware of Brain Drain. The most important Brain Drain movement from Germany is towards North America, by 10,000 students. For this reason, the German Academic Exchange Service (DAAD) established the German academic international network (GAIN). On the other hand, "25\% of the international students request to stay after their studies in Germany, fzs denotes".

$25 \%$ of the international students request to stay after their studies in Germany, fzs denotes. Otherwise in Denmark, "in 2008, 30 \% of incoming students found a job", DSF explains, and "four out of five students wish to find a job after graduation." Denmark therefore expanded the work permit period for international students to three years, as opposed to six months before. Though, it has to be considered that a study from 2008 showed that half of the students of Denmark who finished their degree abroad in 2003 stayed abroad afterwards. Similar outcomes are reported by LSVb (NL), where $64 \%$ of the international students wish to stay after the completion of their studies in the Netherlands. EÜL (ES) explains that "educational migration to Estonia has been stable in the recent years, making $12 \%$ out 
of the whole migration, but it is still about two times lower than the EU average (23\%) and even more for Finland (27\%)." SYL and SAMOK (FI) report that $70 \%$ of the international students are staying at least one year in Finland.

\section{Conclusions and Outlook}

The perception of student mobility is very diverse among the in-depth analysed countries. The concepts of internationalization and welcome culture, in particular to degree mobility, are of different interest to students. Students who decide to study abroad have to face several problems, problems of European complexity due to different elaborated conceptualizations or different approaches to higher education philosophies based on their individual welfare considerations. Internationalization is a dynamic process which is forcing countries, amongst other aspects, to reflect on ethnicity and migration, on their identity, belonging and their concepts of encountering international students. Due to this European complexity, mobile students are affected of multilayered challenges. Following from that, we used the progressive project-title 'Challenges of Student Mobility in a Cosmopolitan Europe' to deliberate our widened approach.

The following table provides an overview of the in-depth analysed countries approach towards student degree mobility (Table 1).

The isolated impact factors show the countries' perception towards student mobility. However, the indicators' impact needs to be seen in correlation with each other. Moreover, other factors, such as a country's welfare system or economic situation, do influence the approach towards student mobility as well, but have not been analysed within the CoSMiCE project. The isolated impact factors also put spotlight on areas where students see the need of modifications to enable student mobility for all.

A main challenge for mobile students is related to financial efforts. Tuition fees, living and study expenses, travel and high income differences between European countries are the main barriers for student mobility. Mobility grants are seen as the main solution to overcome this, by many student representatives. Even though there are already mobility grants and portable grants and loans, mobility is not affordable, irrespective of the individual socio-economic background.

Moreover, the chance to apply for financial support in the host country is often related to work permit and residence permit — regulations to be eligible for official backings are very diverse among countries.

Language policies differ considerably between the countries. On the one hand, they aim to support the integration of international students, by a broad offer of lectures in English, or opportunities to learn the language of a country for free. On the other hand, in some countries, by the requirement of a certain level, language becomes a barrier to receiving grants or access to higher education institutions. In those cases language is used as an exclusive regulation tool. The non-uniform 


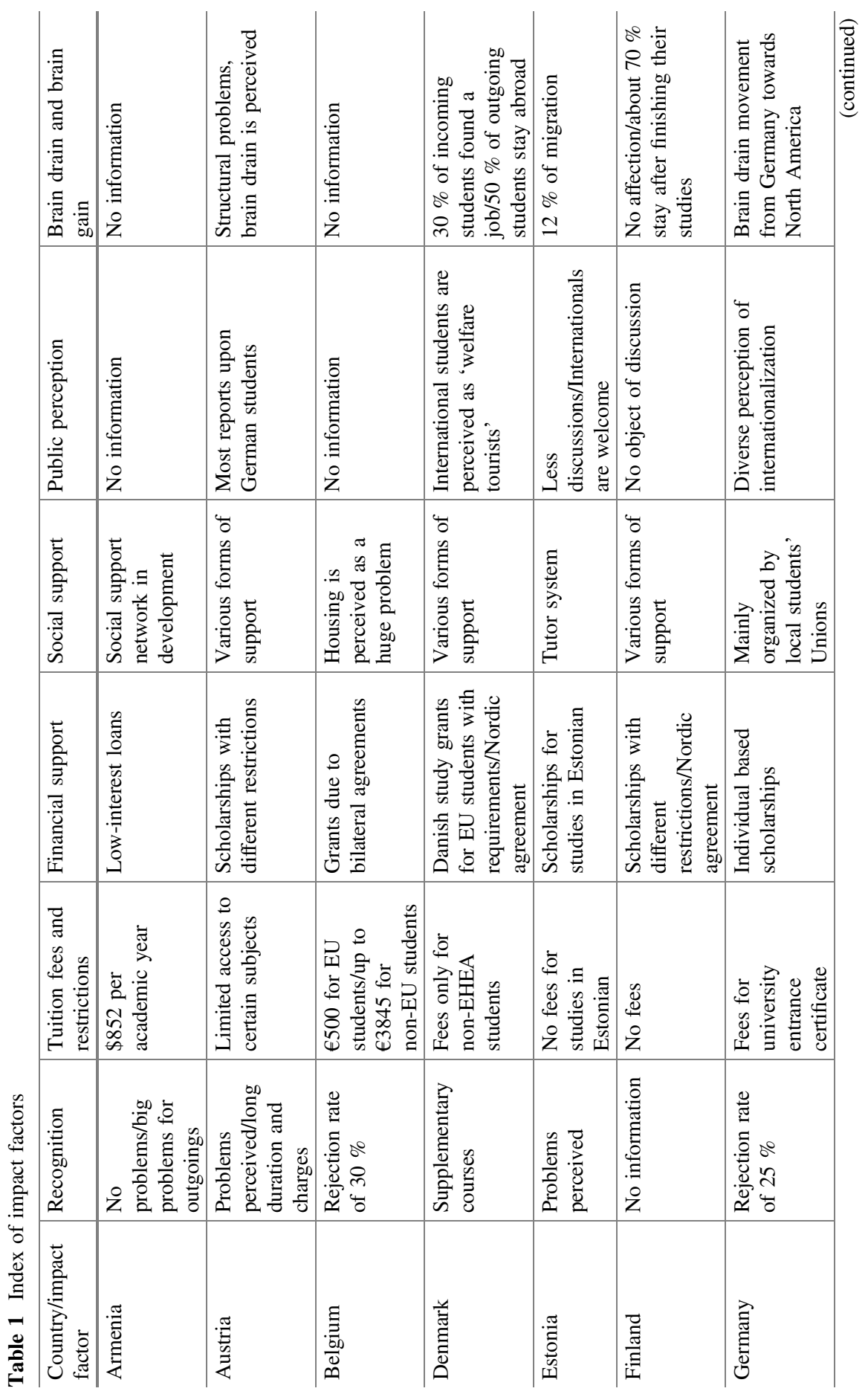




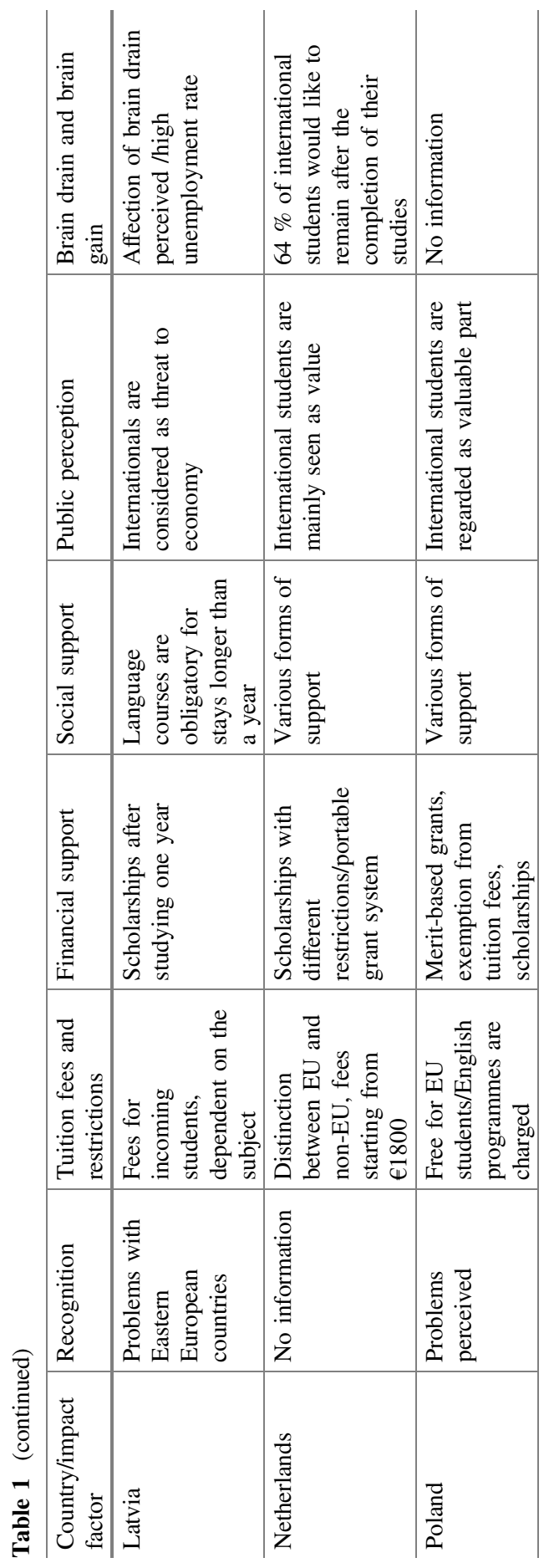


patterns can increase the asymmetries of mobility flows, too, within the social dimension of the mobile students (Cerdeira and Patrocinio 2009).

The balance between mobility flows is seen as very diverse. Countries with a high outbound rate and a low inbound rate are faced with 'Brain Drain' discussions and target to raise incoming mobility. Other countries are faced with a high number of incomings, and are faced with funding and admission issues. Those countries have differing reactions. While some countries developed policies based on solidarity and agreements between the main involved countries, other countries target to solve the problem by exclusion of international students in some areas. While these policies are mostly related to national or even nationalist discussions, others aim for a European discourse. Following from that, the share of principles in admission and funding of HE can be seen as prerequisites for meaningful mobility. Common agreements and negotiations based on democratization and quality should be favoured.

The main findings of the CoSMiCE project show the high diversity between European Countries and their regulations. Access criteria, financial and social support and language policies are not only contrastive, they are regulated by various bodies and are highly complex. Moreover, regulations lack transparency and international comparability. Students barely get the information they need to decide on their individual mobility due to diverse information policies and complex bureaucratic systems. Additionally, the complexity is not only related to educational policies, but also to migration and labour market policies.

Another main finding is related to the public discussion on student mobility. The Public and media perception is very ambivalent among all countries. On the one hand, mobility is seen as attractive and even necessary, on the other hand, discussions on brain drain and imbalanced student mobility flows led to negative perceptions of mobility.

To overcome the barriers towards student mobility, not only broad system reforms in the areas of students support or migration policy are required. Measures are also needed to enhance the information towards students by more transparency, social support, but also creating trust between educational systems and solidarity among European countries. Mobility remains a challenge in the space of a Cosmopolitan Europe, over and above special attention should be given to degree mobility and profound cooperation models within the EHEA and Non-EHEA, to finally overcome a higher education area of contrasting contexts and interplays of protectionist behaviour, rather than solidarity based cooperation.

As this survey has shown, national policies regarding student mobility are influenced by national debates and thus provide ambivalent opportunities for incoming and outgoing students - in terms of financial support, social support, but also migration policies and societal prejudices are factors that enable or hinder mobility. These ambivalent national policies lead to a situation, where students can barely overview and compare the different approaches and are often overwhelmed by the complexity of national systems, even if there are support measures. Degree-seeking students are not only confronted with financial and socio-economic barriers, but are also left alone in preparing, organising and funding their mobility. 
Most likely this will lead to a less socio-economic diversified group of degree students, which should be further researched in future.

A conclusion of the described complex national approaches towards student mobility might be that student degree mobility must become not only an European issue, but an European responsibility to finally create a common European Higher Education Area.

Open Access This chapter is distributed under the terms of the Creative Commons Attribution Noncommercial License, which permits any noncommercial use, distribution, and reproduction in any medium, provided the original author(s) and source are credited.

\section{Annex}

Armenia-ANSA-Armenian National Students' Association

Austria- $O ̈ H-O ̈$ sterreichische Hochschülerinnen- und Hochschülerschaft

Belgium-VVS-Vlaamse Vereniging van Studenten

Denmark — DSF-Danske Studerendes Fællesråd

Estonia_E EÜL_Eesti Üliõpilaskondade Liit

Finland-SYL/SAMOK - Suomen ylioppilaskuntien liitto/Suomen ammattikorkea kouluopiskelijakuntien liitto

Germany- $f z s$ - freier zusammenschluss von StudentInnenschaften

Latvia—LSA-Latvijas Studentu apvieniba

The Netherlands - $L S V b$ - Interstedelijk Studenten Overleg

Poland - PSRP — Students' Parliament of the Republic of Poland.

\section{References}

Grabher A., Petra, W., Martin, U., \& Berta, T. (2014). Student mobility in the EHEA. Underrepresentation in student credit mobility and imbalances in degree mobility. Wien: Institut für Höhere Studien.

Bohnsack, R. (1997). Dokumentarische Methode. In R. Hitzler \& A. Honer (Eds.), Sozialwis senschaftliche Hermeneutik (pp. 191-213). Opladen: Leske and Budrich.

Cerdeira, L., \& Patrocinio, T. (2009). Social support, a key for student mobility in European higher education area. Internationalisation and the Role of University Networks. Paper presented at the EMUNI Conference on Higher Education and Research.

DAAD. (2014). The financial impact of cross-border student mobility on the economy of the host country. http://bit.ly/1qCZXcN.

De Wit, H. (2011). Trends, issues and challenges in internationalisation of higher education. Retrieved from http://bit.ly/1uOWAhg.

Der Standard. (2014). Österreich hat ein Brain Drain Problem. Retrieved from http://bit.ly/ $1 \mathrm{~s} 2 \mathrm{mnFM}$.

EAHEP. (2010). EU-Asia higher education platform. Retrieved from http://www.eahep.org/.

European Commission. (2013). European higher education in the world. COM (2013) 499 final. 
Federal Ministry of the Interior. (2014). Rechtsvorschrift für Niederlassungs- und Aufenthaltsgesetz. Residence Policy. http://bit.ly/X7Z2UJ.

Hawawini, G. (2011). The internationalization of higher education institutions: A critical review and a radical proposal. INSEAD.

Hénard, F., Diamond, L., \& Roseveare, D. (2012). Approaches to internationalisation and their implications for strategic management and institutional practise. A guide for higher education institutions. OECD Higher Education Programme IMHE.

Kehm, B. (2011). Research on Internationalisation in Higher Education. Istanbul.

Knight J (2010). Internationalization and the competitiveness agenda. In L. M. Portnoi, V. D. Rust, \& S. S. Bagley (Eds.), Higher education, policy, and the global competition phenomenon (pp. 205-218). New York: Palgrave Macmillan.

Niederl, A., \& Bader, L. (2014). Maßnahmen zur Studienortattraktivität aus internationaler Perspektive. Unveröffentlicht.

Nordic Council of Ministers for Education and Research. (2012). Agreement on admission to higher education policy. Retrieved from http://bit.ly/X2jtSR.

OECD. (2013). Education at a Glance. OECD Indicators.

OECD. (2013a). Education indicators in focus-2013/05 (July). OECD.

Pechar, H. (2009). Can research universities survive without control over admission? Reflections on Austria's exceptionalism in higher education policy. Journal of Adult \& Continuing Education, 15(2), 142-154.

Rahul, C., \& De Wit, H. (2014). Challenges and opportunities for global student mobility in the future: A comparative and critical analysis. Symposium Books.

SVR für Migration. (2012). Mobile talent? The staying intentions of international students in five EU countries. http://bit.ly/XpItnL.

The Lisbon Treaty. (2007). Treaty the heads of state and government of the 27 EU Member States, esp. Article 165. http://www.lisbon-treaty.org/.

Teichler, U. (2009). Internationalisation of higher education: European experiences. Asia Pacific Education Review, 10(1), 93-106.

UNESCO. (2010). Institute for statistics education database. Retrieved from http://bit.ly/1uDbmsv. 